O. Liuta ${ }^{1}$, orcid.org/0000-0002-3165-7991, S. Lieonov ${ }^{1}$, orcid.org/0000-0001-5639-3008, A. Artyukhov ${ }^{1}$, orcid.org/0000-0003-1112-6891, M. Sushko-Bezdenezhnykh ${ }^{1}$, orcid.org/0000-0002-8433-9989, O. Dluhopolskyi ${ }^{2,3}$, orcid.org/0000-0002-2040-8762
1 - Sumy State University, Sumy, Ukraine

2 - West Ukrainian National University, Ternopil, Ukraine, e-mail: dlugopolsky77@gmail.com

3 - Ternopil Volodymyr Hnatiuk National Pedagogical University, Ternopil, Ukraine

\title{
STUDENT SURVEY AS A TOOL FOR QUALITY ASSURANCE IN HIGHER EDUCATION: THE CASE OF UKRAINIAN UNIVERSITY
}

Purpose. To determine the level of students' interest in internal quality assurance, particularly in passing the survey and changing the teaching quality level and improving teachers' pedagogical skills.

Methodology. For the data collection, a questionnaire was used which included closed-end questions on the quality of teaching and open questions in terms of comments and recommendations of higher education students on the quality of teaching and several questions concerning the share of classes in the discipline attended by the students, ECTS scores, received by students from the relevant disciplines and the average score for the entire period of study.

Findings. Sumy State University (SSU) introduced an online survey of students as the main consumers of educational services regarding the quality of teaching disciplines. Over the last 3 academic years, there has been an increase in the number of teachers whose activities are evaluated by students. There has been an increase in the number of teachers who, according to students, show excellence in teaching, which is a positive trend. If in the 2017-2018 academic year the number of such teachers in SSU was 57 people, then in the 2019-2020 academic year, it increased by $35 \%$ to 77 people. Quality level "Above average" was determined for 120 teachers in the 2017-2018 academic year, and in the 2019-2020 academic year, their number increased by $30 \%$ and amounted to 156 people. It is noteworthy that in the 2019-2020 academic year compared to 2017-2018, there is a reduction in the number of teachers from 71 to 66 people $(7 \%)$, who demonstrated the level of teaching "Low".

Originality. Survey of students on the quality of teaching educational components, on the one hand, allows monitoring students' satisfaction with methods used by the teacher in training and communicating with students, and on the other hand, it is a method to control the institution's authority over the educational service quality and the HEI's mission implementation. It also indicates an increase in students' interest in participating in higher education's internal quality assurance. An important factor influencing the positive dynamics of the teaching quality level is that each semester teachers receive a detailed analysis of students' answers with a visual display for each questionnaire, as well as their comments and suggestions for teaching the relevant discipline through the information service "Personal teacher's office" based on the results of the survey.

Practical value. According to the analysis results of the received information, managerial decisions can be developed and implemented to improve the content and practice of educational components' implementation, improving the professional skills of research and teaching staff, advancement of best pedagogical practices.

Keywords: quality of higher education, quality of teaching disciplines, HEIs, student survey

Introduction. Nowadays, the countries of the world face the task of ensuring a sustainable model of the country's development. Some scholars note that the SDG is based on five basic aspects: people, prosperity, planet, peace and partnership [1]. Attention is drawn to the fact that "people and prosperity" is directly related to the development of the educational sector, which has great influence on achieving sustainable development of the country, these first. Education is a core element of the Sustainable Development Concept. It is not only because of the declaration of SDG 4 within the 2030 Agenda but also its embeddedness in other goals, targets, and indicators [2]. Only a highly educated nation will be able to lead a lifestyle that will contribute to economic, environmental and social prosperity [3]. The Covid-19 pandemic, in turn, has caused new challenges to the higher education system.

It is during periods of crisis that the goals and objectives of education and professionalization of people change radically, as the conditions of their work require new forms of thinking and behavior [4]. Therefore, the issue of improving the quality of higher education is in the focus of scientists and government officials and is one of the main goals of modern politics of any country.

(C) Liuta O., Lieonov S., Artyukhov A., Sushko-Bezdenezhnykh M., Dluhopolskyi O., 2021
The problem of ensuring the efficiency and quality of the organization of higher education, given the versatility and complexity of this process, should be considered in the context of meeting the needs of key consumers of educational services. Thus, the analysis of the provisions of the Standards and Recommendations for Quality Assurance in the European Higher Education Area (ESG 2015) shows the need to actively involve students in the quality assurance processes of higher education, in particular in terms of criteria related to assuring external and internal quality of higher education.

Analyzing the content of ESG 2015 in terms of assuring external quality of higher education, it should be noted that students are defined as full representatives of a group of independent (external) experts (criterion 2.4). The ESG 2015 recommendations for the formation of an internal assurance system provide for the active participation of students in all quality assurance processes, including the formation of quality assurance policy (criterion 1.1), Development, approval, monitoring of programs (criteria 1.2, 1.9), evaluation of teaching quality, teaching resources and support students, public information (criteria 1.3, 1.5, 1.6, 1.8). Thus, today students actively influence the quality of the educational process, which fully complies with the principle of student-centeredness, providing quality educational services and managing the activities of higher education institutions with a focus on student needs. An important factor that ensures the effective implementation 
of the educational process and promotes the formation of students' knowledge that meets modern requirements of the labor market, the latest trends in the specialty and the formation of a competitive specialist is the professionalism of the university teaching staff. The practice of involving students as experts in assessing the quality of teaching is not fundamentally new. The history of its origin and spread in the world has been used for more than a century, which is considered in the works of scientists from different countries.

Literature review. In the modern world it is undeniable that the whole history of human development and the evolution of education lead to the conclusion that learning is the main type of human activity, it is a lifestyle [5], therefore, the educational process and the quality of education need constant improvement, primarily through its evaluation by stakeholders [6].

Student assessment of the quality of teaching disciplines was first introduced in United States universities in the early $20^{\text {th }}$ century. However, the understanding of the importance of this process and the growth of its importance occurred only in the 1970s. It has gradually become clear that student questionnaires are an important tool that can be actively used in the academic environment to assess the effectiveness of teaching. Today, the vast majority of universities in the United States and Canada use the practice of student surveys. This is due to the fact that the universities of these countries have high demands on both the professionalism of teachers and the theoretical knowledge and practical skills acquired by graduates. Understanding that student surveys are a tool for achieving the university's key goals, European higher education institutions have also begun to introduce student surveys to improve the quality of higher education. In addition, universities use not only surveys of students but also graduates in the context of their competencies acquired during their studies to assess the quality of training [6]. It should be noted that the use of student survey results in the context of ensuring a high level of their satisfaction with teaching and learning becomes a key factor influencing the competitiveness of the university in the market of educational services, an important element of advertising campaign and increasing the number of students [7]. As for the management staff of the university, surveys allow making the necessary conclusions regarding the assessment of the qualifications of individual teachers, their communication with students, as well as to identify areas for improving the quality of teaching and, as a result, students' knowledge. Surveys also aim to identify the reasons for the decline in student training [8] and to establish the attractiveness of the graduate in the labor market [9].

During the first years of surveys, they were used only as a feedback tool to improve the quality of teaching and had no consequences for teachers. L. Macfayden, S. Dawson, S. Perst, D. Gašević [10] note that conducting a survey is extremely important directly for the teacher because it allows achieving the following goals: to obtain diagnostic feedback, to measure one's own teaching effectiveness; take into account students' comments on the architecture of the future course.

However, over the years, respondents' responses have been used not only as an opportunity for feedback and recommendations for improvement, but more as a tool whose results are essential for academic career decisions, including tenure, promotion, and appointment [11]. S. Benton and W. Cashin [12] note that the results of the student survey do not so much help teachers to improve their skills and content of disciplines but are the basis for university management to make decisions about the amount of salary and promotion; identification and award of the best teachers, as well as monitoring the quality of teaching in general. In other words, the results of the survey of students on the quality of teaching have increasingly influenced the salary, prestige, opportunities for further employment and career growth of teachers. Given that the results of the survey have become important for management decisions by university management, the survey on teaching has been the subject of harsh criticism from academic faculties [13] and the subject of many studies examining the reliability and validity of surveys in order to determine the extent to which student assessments can objectively affect the career of scientists. There are a number of publications on the inexpediency of using this tool to assess the quality of teaching. Some studies identify the introduction of such surveys even as a violation of academic freedom of the teacher [8]. A number of scholars point out that there are a number of factors that can be potential reasons for bias in survey results and inaccurate assessment of staff quality. Such factors include: students' expectations of assessments, perceptions of complexity and learning load within the course, gender, background characteristics. Therefore, when forming the questions of the questionnaire and the organization of the survey process to obtain an objective result, these factors must be taken into account. In addition, it should be noted that the reliability of the survey, as well as any study, depends on the completeness of the sample. This allows you to reduce subjectivity, highlight existing trends and develop the necessary management decisions. Despite differing views, researchers note the importance of conducting such surveys because they contribute to "effective learning", reduce the number of students who do not graduate, and improve the quality of teaching in general.

The Ukrainian system of expert evaluation of the quality of higher education, unlike the American or European ones, does not have a stable tradition of conducting student surveys, and therefore has relatively limited potential to use survey results to adjust public policy in higher education and improve content and practice, mechanisms of public administration of the education sector [14].

However, the introduction of a new procedure for accreditation of educational programs by the National Agency for Quality Assurance in Higher Education in accordance with the requirements of ESG 2015 has set Ukrainian universities the task of introducing procedures to survey higher education as a necessary tool to improve the quality of teaching, educational components and educational program [15]. This approach requires an analysis of quality assurance systems in terms of student satisfaction, their role in ensuring the quality of education and prospects for their career growth.

Purpose. The purpose of the article is to make conclusions about students' interest in internal quality assurance, particularly in passing the survey and changing the teaching quality level and teachers' pedagogical skills.

Methods. For the data collection, a questionnaire was used, which included closed-end questions on the quality of teaching and open questions in terms of comments and recommendations of higher education students on the quality of teaching and several questions concerning the share of classes in the discipline attended by the studenti, ECTS scores, received by students from the relevant disciplines and the average score for the entire period of study. The questionnaire was created according to the method proposed in [16]. Assessment of the quality of teaching the relevant discipline is conducted in the form of a survey of students and graduate students after completing its study at the end of the module or semester. The questionnaire used to conduct the survey is given in Tables 1, 2.

It should be noted that considerable attention in the questionnaire is paid to assessing the quality of use of modern digital technologies in the teaching of academic disciplines. This is due to the fact that innovations in education have great potential, and modern education is irreversibly changing in the direction of globalization, digitalization and specialization [17]. Consequently, global digitalization requires a change in approaches to the organization of teaching and teaching methods, and hence their evaluation by students.

The method of scores is used to process the survey results. To assess the quality of teaching courses, the appropriate number of points is given for each answer to the questionnaire. The calculation of the result of the survey of respondents (gen- 
eralizing indicator of teaching quality $-G I T Q$ ) is carried out on a separate questionnaire question, a meaningful group of questionnaire questions and/or on all questions of the questionnaire, according to the formula

$$
a_{j}=\sum_{i=1}^{z} x_{i} n_{i},
$$

where $a_{j}$ is the sum of points obtained by the teacher for answering the questionnaire in all disciplines, which were evaluated by applicants for higher education during the relevant period; $j$ is an appropriate teacher; $x_{i}$ is the share of applicants for higher education who chose this answer; $n_{i}$ is the number of points that characterize this answer; $z$ is the number of questions of the questionnaire.

The highest and lowest results are not considered when calculating the GITQ of an individual teacher for each discipline being assessed. If there are several identical results of the specified category, the above does not apply. When calculating the GITQ of an individual teacher for each discipline, the answers of higher education students who noted that they attended less than $30 \%$ of classes in the discipline are not con-

Table 1

Questionnaire for surveying students to determine the quality of teaching disciplines - part I

\begin{tabular}{|c|c|c|c|c|c|}
\hline \multicolumn{6}{|c|}{ I. The quality of teaching disciplines } \\
\hline No & The quality of teaching the discipline & 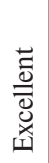 & $\begin{array}{l}\text { Tे } \\
0 \\
0\end{array}$ & 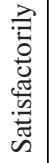 & $\underset{\mathscr{D}}{\mathscr{D}}$ \\
\hline 1. & $\begin{array}{l}\text { Assess how clearly, freely and meaningfully } \\
\text { the teacher explained the material, answered } \\
\text { the questions of students, commented on } \\
\text { difficult moments, singled out the main } \\
\text { theme and cited examples from practice }\end{array}$ & & & & \\
\hline 2. & $\begin{array}{l}\text { Evaluate the teacher's use of interactive } \\
\text { forms of classroom activities: discussions, } \\
\text { active involvement of students in discussions, } \\
\text { training, round tables, problem solving and } \\
\text { other methods }\end{array}$ & & & & \\
\hline 3. & $\begin{array}{l}\text { Assess the extent to which the teacher used } \\
\text { the practice of providing access/links to } \\
\text { educational videos and presentations (from } \\
\text { the Internet and their own methodological } \\
\text { developments) }\end{array}$ & & & & \\
\hline 4. & $\begin{array}{l}\text { Evaluate the teacher's classes using open } \\
\text { electronic platforms (OCW, MiX learning, } \\
\text { Coursera, and so on), own mobile devices } \\
\text { (laptop, tablet, smartphone, and others.) }\end{array}$ & & & & \\
\hline 5. & $\begin{array}{l}\text { Assess how clearly the teacher organized the } \\
\text { independent work of students: identified } \\
\text { requirements, provided recommendations } \\
\text { for homework, identified the necessary } \\
\text { literature, and identified sources for its } \\
\text { receipt }\end{array}$ & & & & \\
\hline 6. & $\begin{array}{l}\text { Evaluate the quality of the organization of } \\
\text { independent work by the teacher using } \\
\text { electronic platforms (OCW, MiX learning, } \\
\text { Coursera, and others), distance courses of } \\
\text { Sumy State University }\end{array}$ & & & & \\
\hline 7. & $\begin{array}{l}\text { Evaluate the possibility of obtaining advice } \\
\text { from the teacher while working on the } \\
\text { discipline }\end{array}$ & & & & \\
\hline 8. & $\begin{array}{l}\text { Assess how seriously and correctly the } \\
\text { teacher treated all students }\end{array}$ & & & & \\
\hline
\end{tabular}

sidered, as the low proportion of respondents did not ensure the relevance of the study and the objectivity of the results.

According to the results of the survey of higher education students on the quality of organization of educational activities, the study on disciplines for the relevant period (autumn/ spring semesters, academic year) is carried out by GITQ ranking of teachers in all disciplines together with the formula

$$
G I T Q=\frac{\sum_{1}^{z} a_{j}}{\sum_{1}^{z} m_{j \max }} \cdot 100 \%,
$$

where $G I T Q$ is an integrative indicator of quality of the organization of educational activity of the teacher on all disciplines estimated by applicants of higher education during the corresponding period; $m j$ max is the possible amount of points that can be obtained by answering the questionnaire.

The indicator of the minimum respondents' number and the minimum share of students who participated in the survey

Table 2

Questionnaire for surveying students to determine the quality

\begin{tabular}{|c|c|c|c|c|c|}
\hline \multicolumn{6}{|c|}{ II. Evaluation of the quality of communication with students } \\
\hline & $\begin{array}{l}\text { Component assessments of the } \\
\text { quality of communication with } \\
\text { students }\end{array}$ & \multicolumn{2}{|c|}{$\begin{array}{l}\text { Corresponds } \\
\text { to reality }\end{array}$} & \multicolumn{2}{|c|}{$\begin{array}{l}\text { Absolutely } \\
\text { not true }\end{array}$} \\
\hline 9. & $\begin{array}{l}\text { The teacher adheres to the start } \\
\text { and end time of classes }\end{array}$ & & & & \\
\hline 10. & $\begin{array}{l}\text { The teacher acquainted the } \\
\text { students with the regulations, } \\
\text { which specify the evaluation } \\
\text { criteria, and clearly followed } \\
\text { them }\end{array}$ & & & & \\
\hline 11. & $\begin{array}{l}\text { The teacher objectively } \\
\text { assessed all types of tasks } \\
\text { provided by the regulations }\end{array}$ & & & & \\
\hline 12. & $\begin{array}{l}\text { The course was taught in } \\
\text { Ukrainian (English according } \\
\text { to the curriculum) }\end{array}$ & & & & \\
\hline 13. & $\begin{array}{l}\text { During the quarantine } \\
\text { restrictions, the teacher held } \\
\text { regular classes }\end{array}$ & & & & \\
\hline \multicolumn{6}{|c|}{ III. General assessment of the teacher's work in the discipline } \\
\hline 14. & $\begin{array}{l}\text { Your overall assessment of the } \\
\text { teacher's work in this discipline }\end{array}$ & 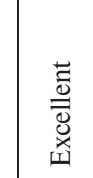 & $\begin{array}{l}\text { D } \\
8 \\
0\end{array}$ & 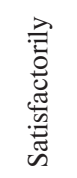 & $\stackrel{\mathscr{D}}{\mathscr{D}}$ \\
\hline 15. & $\begin{array}{l}\text { Your wishes, remarks and } \\
\text { suggestions on the quality of the } \\
\text { organization of educational activities } \\
\text { in the study of the discipline }\end{array}$ & & & & \\
\hline A. & $\begin{array}{l}\text { What proportion of classes in the } \\
\text { discipline did you } \\
\text { personally attend? }\end{array}$ & $\begin{array}{l}\text { A. } 1 . \\
\text { A. } 2 . \\
\text { A. } 3 \text {. } \\
\text { A. } 4 \text {. } \\
\text { A. } 5 \text {. } \\
\text { indiv }\end{array}$ & $\begin{array}{l}\text { Mor } \\
60- \\
30- \\
\text { Less } \\
\text { I ha } \\
\text { dual }\end{array}$ & $\begin{array}{l}90 \% \\
0 \% \\
0 \% \\
30 \% \\
\text { e an } \\
\text { chedule }\end{array}$ & \\
\hline B. & $\begin{array}{l}\text { What grade on the ECTS scale did } \\
\text { you get from this } \\
\text { discipline? }\end{array}$ & $\begin{array}{l}\text { B.1. } \\
\text { B.3. } \\
\text { B.5. }\end{array}$ & $\begin{array}{l}; \text { B. } 2 \\
\text {; B. } \\
\text {; B. } 6\end{array}$ & $\begin{array}{l}\text { Fx; } \\
\text { D; } \\
\text { B; B.7 }\end{array}$ & \\
\hline C. & $\begin{array}{l}\text { Your average score for the entire } \\
\text { period of study }\end{array}$ & $\begin{array}{l}\text { C.1. } \\
\text { C.3. } \\
\text { C.5. }\end{array}$ & $\begin{array}{l}0-63 \\
4-80 \\
0-10\end{array}$ & $\begin{array}{l}\text { C.2. } 64 \\
\text { C.4. } 81 \\
0\end{array}$ & \\
\hline
\end{tabular}
of teaching disciplines - part II-III 
are used to ensure the reliability of the results when calculating the normalized value of the generalizing indicator of teaching quality $\left(G I T Q^{n}\right)$.

For those lecturers whose activities are evaluated according to the conditions presented above, the generalizing indicator of teaching quality $\left(G I T O^{n}\right)$ for the relevant period is normalized according to the absolute normalization formula

$$
G I T O^{n}=\frac{G I T Q_{j}-G I T Q \min }{G I T Q \max -G I T Q \min } \cdot 100 \%,
$$

where $G I T O^{n}$ is normalized value of the generalizing indicator of teaching quality for the relevant period; $G I T O_{j}$ is value of the lecturer's generalizing indicator of teaching quality for the relevant period; GITQ min is minimum value of generalizing indicator of teaching quality for the relevant period; GITQ max is maximum value of the generalizing indicator of teaching quality for the relevant period.

The generalizing indicator of teaching quality is determined by rating technologies and distributes teachers according to their value of IITO $^{n}$ by five levels: high (about $10 \%$ of teachers whose activities are in accordance with the established limits), above average (about $20 \%$, respectively), medium (about $40 \%$, respectively), below average (about $20 \%$, respectively), low (about $10 \%$, respectively), including critical (if $G I T O^{n}$ is within $0-35 \%$ ).

Results. Based on the study on the best practices from European universities since 2017, Sumy State University introduced an online survey of students as the main consumers of educational services regarding the quality of teaching disciplines. The survey is conducted exclusively online through the information service "Student's Personal Cabinet", which has many advantages. First of all, an online survey provides an opportunity to attract a significant contingent of respondents since students can answer questions conveniently and without identifying their identity. Given that access to the survey is provided through the "Student's Personal Cabinet", other persons not related to the object of expert attention cannot participate. These aspects increase the objectivity and reliability of the results. The availability of software developed by university specialists for the survey contributes to the result processing efficiency and the impartiality of the findings. One should note that the students' involvement in the expert evaluation of the teaching discipline quality does not require significant amounts of material and technical resources both for the survey and to process its results.

SSU has the system of student survey regarding the teaching quality today that acts as an element of a centralized university structure of internal quality assurance and cover five main stages: conducting a survey, determining the results of the interview using the scoring method, analysis of respondents to assess compliance with the requirements for the minimum number and share of students who have evaluated the discipline, normalization of the indicators, building a rating of teachers according to the results of the survey to determine the level of quality: high, above average, medium, below average, low, critical (Table 3) and appropriate management decisions.

The algorithm to organize the interviewing of students about the teaching quality is shown in Fig. 1. The teaching quality is assessed to ensure the students' rights to receive quality education and consider students' proposals to improve the teaching quality. It provides information conditions to form a holistic view of the educational activity quality. This survey is based on the principles of transparency, objectivity, academic integrity \& voluntariness. This study allowed us to draw few conclusions about students' interest in internal quality assurance, particularly in passing the survey and changing the teaching quality level and teachers' pedagogical skills.

Fig. 2 shows the indicators of student participation in the survey on the teaching discipline quality for three academic years: 2017-2018, 2018-2019, and 2019-2020. The data
Table 3

Description of teaching quality levels

\begin{tabular}{|l|l|}
\hline $\begin{array}{c}\text { Quality } \\
\text { level }\end{array}$ & \multicolumn{1}{|c|}{ Description } \\
\hline High & $\begin{array}{l}\text { The teacher has a high level of professionalism, skillfully } \\
\text { forms students' interest in the discipline, he or she is } \\
\text { organized and objective in assessing their academic } \\
\text { achievements }\end{array}$ \\
\hline $\begin{array}{l}\text { Above } \\
\text { average }\end{array}$ & $\begin{array}{l}\text { The level of educational activity organization is rather } \\
\text { high. The teacher provides quality material, is able to } \\
\text { organize independent work of students, is disciplined in } \\
\text { the implementation of their professional responsibilities }\end{array}$ \\
\hline Average & $\begin{array}{l}\text { The professionalism level is satisfactory, but the work of } \\
\text { the teacher as a researcher and pedagogical worker has a } \\
\text { number of shortcomings, indicated by the evaluation } \\
\text { scores of the questionnaire }\end{array}$ \\
\hline $\begin{array}{l}\text { Below } \\
\text { average }\end{array}$ & $\begin{array}{l}\text { The professionalism level is satisfactory, but there are } \\
\text { significant shortcomings, indicated by the evaluation } \\
\text { scores of the questionnaire, in the teacher's work in } \\
\text { some educational activities }\end{array}$ \\
\hline Low & $\begin{array}{l}\text { There are significant shortcomings in the discipline } \\
\text { teaching organization }\end{array}$ \\
\hline Critical & $\begin{array}{l}\text { There are unacceptable violations in the } \\
\text { organization of teaching discipline }\end{array}$ \\
\hline
\end{tabular}

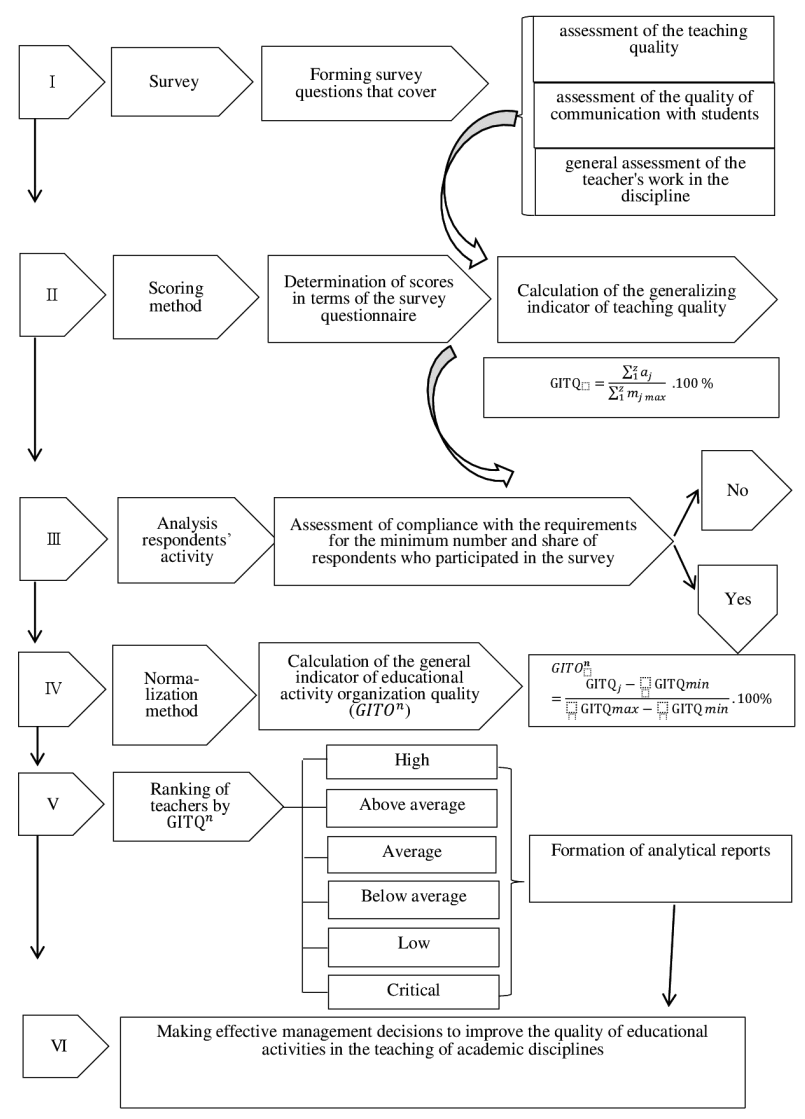

Fig. 1. Algorithm for organizing the interviewing of students about the teaching quality (6 stages)

shown in Fig. 2 give grounds to draw conclusions about the growth of student activity in the survey on the academic discipline quality. If $58.44 \%$ of the total number of students from SSU took part in the survey during the autumn semester of 2017-2018 academic year, then for similar periods of 20182019 and 2019-2020 academic year, this figure increased to 69.05 and $76.68 \%$, respectively. In the spring semester of 


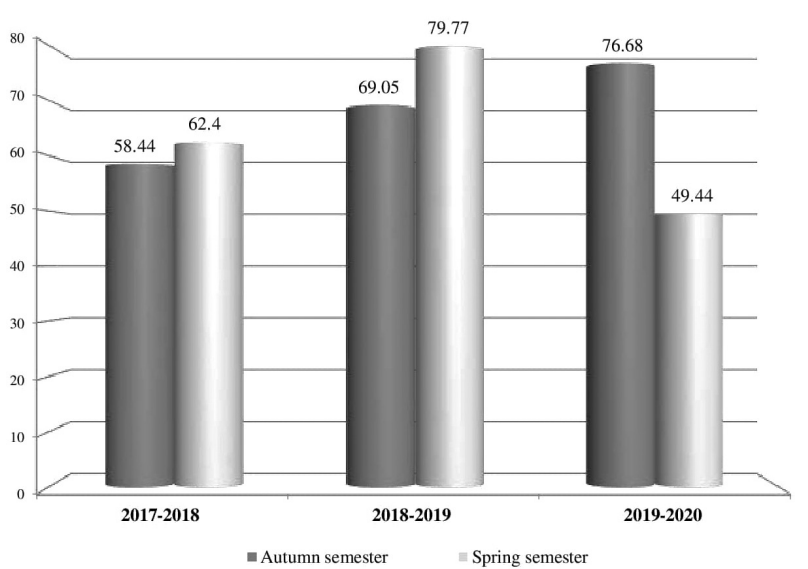

Fig. 2. Data on student participation in the survey on the teaching quality, \%

2018-2019 academic year, the share of students who took part in the survey increased by $17.37 \%$ compared to the same period in 2017-2018 academic year and amounted to $79.77 \%$. It is the highest figure for the last three years. The situation with students' participation in the survey was deteriorated in the spring semester. It was caused by the introduction of quarantine restrictions, distance learning and the students' adaptation to new learning conditions. However, despite the conditions of the pandemic, it can be argued that the level of student interest in participating in this survey has increased. It is primarily due to the fact that after summarizing the survey students receive generalized information through the information service "Student's Personal Cabinet" not only about the ranking of teachers by quality levels, but also about what management decisions were made based on their evaluation. This practice is fully in line with $\S 1.9$ of ESG 2015 , which states "Any action planned or taken as a result of the review should be communicated to all stakeholders". Gradually, students are realizing that they are active participants in the educational process, and their opinion is important because it can describe the features of teaching certain disciplines and to draw attention to the systemic problems.

According to the SSU experience, the student surveys also have an important impact on increasing the quality of teaching. One should note that the data presented in Fig. 3 allow us to draw a number of conclusions. Firstly, over the last three academic years, there has been an increase in the number of teachers whose activities are evaluated by students. It also indicates an increase in students' interest in participating in higher education's internal quality assurance. Secondly, the growth of the number of teachers who, according to students, have a high level of teaching is a positive trend. If in the 20172018 academic year the number of such teachers was 57 peo-

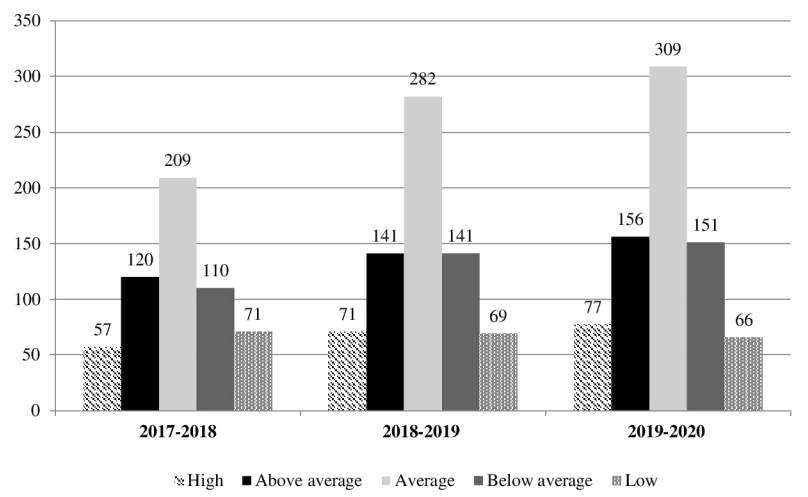

Fig. 3. Data on the levels of teaching quality of lecturers, individuals ple, then in 2019-2020 academic year, it increased by $35 \%$ to 77 people. Quality level "Above average" in 2017-2018 academic year was determined for 120 teachers, and in 2019-2020 academic year, their number increased by $30 \%$ and amounted to 156 people. It is noteworthy that in the 2019-2020 academic year compared to 2017-2018, there is a reduction in the number of teachers from 71 to 66 people $(7 \%)$, who demonstrated the "Low" level of teaching. An important factor influencing the positive dynamics of the teaching quality level is that each semester teachers receive a detailed analysis of students' answers with a visual display (graphs, diagrams, and so on.) for each questionnaire, as well as their comments and suggestions for teaching the relevant discipline through the information service "Personal teacher's office" based on the results of the survey.

According to the evaluation analysis results, the applicants' proposals to improve the education quality are considered, the annual competition "The best teacher through the eyes of students" is held and such teachers are awarded. Besides, teachers, whose teaching quality is highly appreciated by students, are involved in webinars, seminars, lectures in advanced training programs to disseminate best practices. Teachers who have demonstrated a "low" level of quality in the organization of educational activities receive recommendations for advanced training courses.

Thus, interviewing students on the teaching quality is a driving force that helps to increase teachers' interest in their training and improve student performance; formation of highly qualified scientific and pedagogical staff at the university, creation of conditions for professional growth and development of teachers; identification of problematic issues in the formation of the human resources of research and teaching staff of the university. As a result, it leads to an increase in the higher education quality that notes as "a factor of the competitiveness of individuals, territories and the state as a whole, a defining tool for local development management" [18].

Discussion. The survey of students on the teaching quality, methods to process the obtained results and managerial decisions made as a result of the survey should be the researchers' focus since it is necessary to continue working to improve the reliability and validity of surveys and the students' authority level, their ability to influence the careers of academic scholars.

One should note that the validity, quality and relevance of the methods and tools applied by the expert used for the survey can have a significant impact not only on the quality and efficiency of the study results but also on the confidence level of all stakeholders in the conclusions and activities carried out based on the survey results. Therefore, when organizing a student survey on the teaching quality, it is necessary to focus on several aspects. First of all, it is necessary to ensure the relevance of the content and architecture of the survey to the strategic goals of the internal quality assurance system and the strategy of human resources development of the university. It is reasonable to form the survey in cooperation with internal stakeholders - students and academic staff and external stakeholders employers and graduates, who can offer adjustments to its content following the modern labor market requirements. The surveys should be conducted systematically using scientifically sound methods and those who have passed the appropriate testing to obtain comparable results and make managerial decisions. If the survey is conducted online, an essential aspect of its organization is choosing the perfect software product and platform for the survey, which will fully ensure compliance with the principle of anonymity, one of the key factors determining the reliability of the results. One of the key points in the student survey organization should be the representativeness of the respondents' sample, their voluntary participation, the publication of information about the survey results, the obtained conclusions and the taken managerial measures.

In the conditions of the students' online survey, in our opinion, it is perspective to assess the risk of information loss 
management caused by personnel, technical problems, software, cybercrime, virus attacks and other factors influencing possible incidents $[19,20]$.

Conclusions. Thus, the student surveys on the quality of discipline teaching are, first of all, an effective tool for obtaining information about the state and trends to provide the staff of higher education institutions.

Survey of students on the quality of teaching educational components at the university level, organizational and methodological aspects of which were considered in this study, on the one hand, allows monitoring students' satisfaction with methods used by the teacher in training and communicating with students. On the other hand, it is a method to control the institution's authority over the educational service quality and the HEI's mission implementation. According to the analysis results of the received information, managerial decisions can be developed and implemented to improve the content and practice of implementing educational components, improving the professional skills of research and teaching staff, advancement of best pedagogical practices.

Besides, the survey allows obtaining objective information on the study's focus, namely identifying shortcomings in the teaching of disciplines and research and teaching staff professionalism. Besides, surveys identify problematic aspects of the system assuring the internal quality in general. Thus, the results obtained during the survey can improve the regulatory framework in streamlining the organization, conduct, and use of student survey results. In the context of the observed issues, further directions of research can be related to improving the content of the survey on the teaching quality, substantiation of methods to process the results, and organizing student surveys on the educational program quality and ranking educational programs.

Acknowledgement. This research was funded by the grants from the Ministry of Education and Science of Ukraine "Reforming the lifelong learning system in Ukraine for the prevention of the labor emigration: a coopetition model of institutional partnership" (reg. n. 0120U102001), "Convergence of economic and educational transformations in the digital society: modeling the impact on regional and national security" (reg. n.0121U109553).

\section{References.}

1. Vasilyeva, T., Bilan, S., Bagmet, K., \& Seliga, R. (2020). Institutional development gap in the social sector: crosscountry analysis. Economics and Sociology, 13(1), 271-294. https//doi. org/10.14254/2071-789X.2020/13-1/17.

2. Vorontsova, A., Shvindina, H., Mayboroda, T., Mishenina, H., \& Heiets, I. (2020). The impact of state regulation in a sphere of education on sustainable development of national economy. Problems and Perspectives in Management, 18(4), 275-288. https//doi.org/10.21511/ ppm.18(4).2020.23

3. Vorontsova, A., Vasylieva, T., Bilan, Y., Ostasz, G., \& Mayboroda, T. (2020). The influence of state regulation of education for achieving the sustainable development goals: Case study of central and eastern European countries. Administratie Si Management Public, 34, 6-26. https//doi.org/10.24818/amp/2020.34-01.

4. Lyeonov, S., \& Liuta, O. (2016). Actual problems of finance teaching in Ukraine in the post-crisis period. The financial crisis: Implications for research and teaching, 145-152. https//doi.org/10.1007/9783-319-20588-5 07 .

5. Onopriienko, K., Onopriienko, V., Petrushenko, Y., \& Onopriienko, I. (2021). Environmental education for youth and adults: A bibliometric analysis of research. E3S Web of Conferences, 234. https//doi. org/10.1051/e3sconf/202123400002.

6. Pavlenko, O., Martynets, V., Dreval, O., \& Smolennikov, D. (2020). Analysis of influence of the quality of specialist training on social and economic development. Quality - Access to Success, 21(176), 81-86. Retrieved from https//www.scopus.com/record/display.uri?eid $=2$-s2.0-85086159333\&origin $=$ resultslist.

7. Wearring, A., Le, H., Wilson, R., \& Arambewela, R. (2015). The international student's experience: An exploratory study of students from Vietnam. The International Education Journal: Comparative Perspectives, 14(1), 71-89.
8. Kaya, H. D., \& Kwok, J. S. (2020). An Application Of Stock-Trak In 'Investments': What Common Mistakes Do Students Make While Studying Socioeconomic Processes? SocioEconomic Challenges, 4(1), 5-16. https//doi.org/10.21272/sec.4(1).5-16.2020.

9. Agnes, U. T. (2020). Transformation of Z-Generation in the context of globalization and place marketing: the case of Hungarian students. SocioEconomic Challenges, 4(1), 28-35. https://doi. org/10.21272/sec.4(1).28-35.2020.

10. Macfadyen, L.P., Dawson, S., Prest, S., \& Gašević, D. (2016). Whose feedback? A multilevel analysis of student completion of end-ofterm teaching evaluations. Assessment \& Evaluation in Higher Education, 41(6), 821-839. https://doi.org/10.1080/02602938.2015.1044421. 11. Davidovitch, N., \& Soen, D. (2011). Student Surveys and Their Applications In Promoting Academic Quality In Higher Education. Journal of College Teaching \& Learning, 8(6), 31-46. https://doi. org/10.19030/tlc.v8i6.4277.

12. Benton, S. L., \& Cashin, W. E. (2014). Student Ratings of Instruction in College and University Courses. In: M.B. Paulsen (Ed.). Higher Education: Handbook of Theory and Research, 279-326.

13. Davidovitch, N., \& Soen, D. (2009). Myths and facts about student surveys of teaching the links between students evaluations of faculty and course grades. Journal of College Teaching \& Learning, 6(7), 41-49. https://doi.org/10.19030/tlc.v6i7.1124.

14. Moroz, V. (2018). Online survey of students in the quality assurance system of higher education. Information technologies and teaching aids, 6(68), 235-250.

15. Stukalo, N., \& Dluhopolskyi, O. (2020). Educational programs accreditation in pandemic times: challenges for NAQA (Ukraine). Revista Romaneasca pentru Educatie Multidimensionala, 12(1Sup2), 167172. https://doi.org/10.18662/rrem/12.1sup2/260.

16. Taherdoost, H. (2016). How to Design and Create an Effective Survey/Questionnaire: A Step by Step Guide. International Journal of Academic Research in Management, 4(5), 37-41.

17. Skrynnyk, O., \& Vasilyeva, T. (2020). Comparison of open learning forms in organizational education. CEUR Workshop Proceedings. Retrieved from https://www.researchgate.net/publication/34608200. 18. Pryima, S., Dayong, Y., Anishenko, O., Petrushenko, Y., \& Vorontsova, A. (2018). Lifelong learning progress monitoring as a tool for local development management. Problems and Perspectives in Management, 16(3), 1-13. https//doi.org/10.21511/ppm.16(3).2018.01.

19. Stavytskyy, A., Dluhopolskyi, O., Kharlamova, G., Karpuk, A., \& Osetskyi, V. (2019). Testing the fruitfulness of the institutional environment for the development of innovative-entrepreneurial universities in Ukraine. Problems and Perspectives in Management, 17(4), 274-288. 20. Yarovenko, H., Bilan, Y., Lyeonov, S., \& Mentel, G. (2021). Methodology for assessing the risk associated with information and knowledge loss management. Journal of Business Economics and Management, 22(2), 369-387. https//doi.org/10.3846/jbem.2021.13925.

\section{Опитування студентів як інструмент забезпечення якості вищої освіти: приклад українського університету}

\footnotetext{
О. В. Люта ${ }^{1}$, С. В. Леонов ${ }^{1}$, А. С. Артюхов ${ }^{1}$, М. Г. Сушко-Безденежних ${ }^{1}$, О. В. Длугопольський ${ }^{2,3}$ 1 - Сумський державний університет, м. Суми, Україна 2 - Західноукраїнський національний університет, м. Тернопіль, Україна, e-mail: dlugopolsky77@gmail.com 3 - Тернопільський національний педагогічний університет імені В. Гнатюка, м. Тернопіль, Україна
}

Мета. Встановлення рівня зацікавленості студентів у внутрішньому забезпеченні якості освіти, зокрема, у проходженні опитування та зміні рівня викладання, удосконаленні педагогічних навичок викладачів.

Методика. Для збору даних була використана анкета, що включала закриті питання щодо якості викладання та відкриті питання з коментарями й рекомендаціями студентів ЗВО щодо якості викладання, кількості занять із дисциплін, що відвідували студенти, балів ECTS, отриманих студентами, і середнього балу за весь період навчання.

Результати. Сумський державний університет (СумДУ) провів онлайн-опитування студентів як основних 
споживачів освітніх послуг шодо якості викладання навчальних дисциплін. За останні 3 роки спостерігається збільшення кількості викладачів, діяльність яких оцінюється студентами СумДУ. Зростає зацікавленість студентів в участі у внутрішньому забезпеченні якості вищої освіти. Зростає кількість викладачів, які, на думку студентів, мають високий рівень викладання, що є позитивною тенденцією. Якщо у 2017-2018 навчальному році кількість таких викладачів у СумДУ становила 57 осіб, то у 2019-2020 навчальному році вона зросла до 77 осіб (на $35 \%$ ). Рівень якості «Вище середнього» у 2017-2018 навчальному році було виставлено за опитуванням для 120 викладачів, а у 2019-2020 навчальному році їх кількість зросла до 156 осіб (на 30 \%). У 2019-2020 навчальному році порівняно із 2017-2018 роками спостерігається зменшення кількості викладачів із 71 до 66 осіб (на $7 \%$ ), які продемонстрували рівень викладання «Низький».

Наукова новизна. Опитування студентів за якістю викладання освітніх компонентів, з одного боку, дозволяє контролювати їх задоволеність методами, що використовуються викладачем при навчанні та спілкуванні зі сту- дентами, а з іншого боку, є методом контролю повноважень університету за якістю освітніх послуг і реалізацією його місії. Важливим фактором, що впливає на позитивну динаміку рівня якості викладання, є те, що викладачі кожного семестру отримують детальний аналіз відповідей студентів із візуальним відображенням для кожної анкети, а також свої зауваження та пропозиції щодо викладання відповідної дисципліни через інформаційну службу «Особистий кабінет викладача» за результатами опитування.

Практична значимість. За результатами аналізу отриманої інформації можуть бути розроблені й реалізовані управлінські рішення для поліпшення змісту та практики реалізації освітніх компонентів, підвищення кваліфікації наукових і педагогічних кадрів, поширення передових педагогічних практик.

Ключові слова: якість вищої освіти, якість викладання дисциплін, ЗВО, опитування студентів

Recommended for publication by T.V.Pimonenko, Doctor hab. The manuscript was submitted 30.02.21. 